\title{
ANIMAL RESEARCH PAPER Chronic heat stress and feed restriction affects carcass composition and the expression of genes involved in the control of fat deposition in broilers
}

\author{
J. DE ANTONIO ${ }^{1}$, M. F. FERNANDEZ-ALARCON ${ }^{1}$, R. LUNEDO ${ }^{1}$, G. H. SQUASSONI ${ }^{2}$, \\ A. L. J. FERRAZ ${ }^{3}$, M. MACARI ${ }^{1}$, R. L. FURLAN ${ }^{1}$ AND L. R. FURLAN ${ }^{3 *}$ \\ ${ }^{1}$ Department of Animal Physiology and Morphology, São Paulo State University, São Paulo, Brazil \\ ${ }^{2}$ Aquaculture Center of UNESP, São Paulo State University, São Paulo, Brazil \\ ${ }^{3}$ Mato Grosso do Sul State University (UEMS), Aquidauana, Brazil
}

(Received 3 September 2015; revised 27 September 2017; accepted 28 September 2017; first published online 2 November 2017)

\section{SUMMARY}

Heat stress (HS) is among the major limiting factors to growth of broilers. Heat stress also results in changes in the characteristics of the carcass, such as an increase in fat deposition. The molecular mechanisms responsible for fat deposition in broilers as a response to HS remain unknown. The current study aimed to describe the molecular mechanisms associated with the effects of high temperature and feed restriction due to chronic heat exposure at $32{ }^{\circ} \mathrm{C}$, and to describe the resulting changes in the growth performance and carcass characteristics of the broilers at 21 and 42 days of age. In the current study, 441 male Cobb-500 ${ }^{\circledR}$ broilers were subjected to three treatments that differed in rearing temperature and feeding regime: chronic HS fed ad libitum (HS/AL), thermoneutral environment fed ad libitum (TN/AL) and TN and pair-feeding on the feed intake (FI) of the heat-exposed group (TN/PF). HS increased fat content in the breast and wings and decreased fat content in the legs, but did not influence abdominal fat. These effects occurred regardless of reducing consumption induced by HS. Furthermore, HS, independently of reduced $\mathrm{Fl}$, increased liver sterol-regulatory element-binding protein-1 (SREBP-1) mRNA in both ages and growth hormone receptor (GHR) mRNA at 42days, whereas feed restriction reduced GHR mRNA only at 21 days. In conclusion, increased fat content in the breast and wings was accompanied by a higher gene expression of GHR and SREBP-1, suggesting the involvement of both genes in the control of fat deposition in broilers exposed to HS.

\section{INTRODUCTION}

According to the FAO (2012), each year over 59 billion broilers are slaughtered worldwide to meet the growing demand from human consumption. Due to the increasing demand for meat, farmers have begun to select broilers for high growth rate, breast meat yield and the efficiency of feed conversion (Arnould \& Leterrier 2007; Estevez 2007).

The best results for rearing broilers are achieved with optimum environmental conditions. For example, temperature is one of the major limiting factors for broiler growth (Lara \& Rostagno 2013). Broilers reared

\footnotetext{
* To whom all correspondence should be addressed. Email: cedral@caunesp.unesp.br
}

at high temperatures exhibit low feed intake $(\mathrm{FI})$ and consequently poor performance rates (De Faria Filho et al. 2007; Zuo et al. 2015). It was estimated that direct effects of high temperature on broiler metabolism are responsible for $46-50 \%$ of weight gain losses in broilers reared in warm environments, and the remaining $50-54 \%$ losses are due to FI reduction (Abu-Dieyeh 2006; Campos et al. 2013).

In addition to a decrease in productive performance of broilers, heat exposure also induces changes in their carcasses. Broilers reared in environments with high temperatures have more fat deposition and less proteins in the carcass (Zhang et al. 2012), resulting from a low basal metabolic rate and reduced physical activity (Cheng et al. 1997; Oliveira Neto et al. 2000). 
The changes in productive performance and carcass composition of broilers exposed to high temperature are also attributed to lower Fl. Malnutrition alters plasma concentration of growth-controlling hormones in broilers (Gonzales et al. 1998; Buyse et al. 2000). More specifically, decreased levels of expression of growth hormone receptor (GHR) (Zhao et al. 2004) and liver insulin-like growth factor 1 (IGF-I) (Kita 1998) are observed, which ultimately reduces muscle growth and increases the mobilization of energy for homeostasis (Buyse \& Decuypere 1999). Furthermore, broilers reared at high temperatures show a lower concentration of plasma growth hormone (GH) (Buyse et al. 2000).

As suggested above, heat stress (HS) and lower FI regulate the effect of $\mathrm{GH}$ on energy homeostasis, which may be associated with modifications of carcasses in broilers exposed to high temperature. To further investigate the modifications of carcasses, genes involved in energy metabolism can be identified and analysed for their role in fat deposition in broiler carcasses. Energy metabolism is maintained by the liver, where nutrients from the diet or from corporeal deposition are used in metabolic pathways regulated by neural and hormonal signals (Hillgartner et al. 1995). These hormonal signals regulate several genes including transcription factors such as the sterol regulatory element-binding protein-1c (SREBP-1) and the carbohydrate response elementbinding protein (ChREBP), which are responsible for regulating energy homeostasis (Shimano et al. 1999). The reduced expression of these two transcription factors observed during fasting (Richards et al. 2003; Wang et al. 2009) is correlated with the expression of genes for several enzymes from energy metabolism (Proszkowiec-Weglarz et al. 2009).

It still unknown whether fat deposition in broilers exposed to high temperatures is due to a reduction in FI or to the direct effect of HS. Considering the relationship between the environment and its role in gene expression as mentioned above, SREBP-1 and ChREBP become candidates for regulating fat deposition in broiler carcasses induced from HS. These transcription factors have not been investigated to identify their association with fat deposition in broilers as a response to HS.

The present study was performed to identify and describe the molecular mechanisms associated with the effects of high temperature and feed restriction due to chronic heat exposure at $32{ }^{\circ} \mathrm{C}$, and to describe the productive performance and the characteristics of the carcass under such condition. To describe the involvement of the molecular mechanisms, the abundance of mRNA related to growth and energy metabolism was measured in the liver of broilers reared with high temperatures. Furthermore, the pair-feeding (PF) experimental approach isolated the specific effects of HS and feed restriction on growth performance and body composition.

\section{MATERIAL AND METHODS}

This experiment was performed following the rules of the Animal Ethics Committee (CEUA) of the School of Agriculture and Veterinary Science, São Paulo State University.

\section{Broilers and experimental design}

The broilers were reared in floor pens $1.7 \times 2.5 \mathrm{~m}^{2}$ in three climatic chambers with wood shavings used as litter $(10 \mathrm{~cm}$ deep). The side and top walls of the chambers were composed of insulating material and each chamber was equipped with four exhaust fans. To ensure the consistency of the temperature, cooling systems and infrared lamps were controlled by thermostats. The broilers were reared with continuous light for $24 \mathrm{~h}$ (15 lux).

The broilers used in the present study were evaluated from 7 to 42 days of age: until 7 days old they were kept in a thermoneutral (TN) environment (Anon 2003) with average temperature and relative humidity of $31 \cdot 8 \pm 0 \cdot 10{ }^{\circ} \mathrm{C}$ and $58.6 \pm 2 \cdot 66 \%$, respectively. At 7 days of age, 441 male Cobb $500^{\circledR}$ broilers were distributed in a completely randomized experimental design, in a 'pair-feeding' system as described in Geraert et al. (1996). The PF schedule was used to separate temperature effects from FI effects, by providing broilers reared in TN environments the same amount of feed as that consumed by stressed broilers on the previous day. The experimental design consisted of three treatments and seven replicates per treatment, each replicate with 21 broilers. Each treatment differed by the temperature at which broilers were reared and the feeding regime as follows: chronic HS fed ad libitum (HS/AL), TN environment fed ad libitum (TN/AL), and TN and PF on the FI of the group exposed to HS (TN/PF; Table 1). For this, each floor pen had one individual feeder and one individual drinker. The FI of broilers in the HS/AL treatment was measured daily at 8.00 a.m. for the seven replicates. Individual daily FI was calculated as the 
Table 1. Environmental temperature and relative humidity registered at climatic chambers during the experiment

\begin{tabular}{|c|c|c|c|c|}
\hline \multirow[b]{2}{*}{ Periods } & \multicolumn{2}{|l|}{$\mathrm{HS} / \mathrm{AL}$} & \multicolumn{2}{|c|}{ TN/AL and TN/PF } \\
\hline & $\mathrm{T}^{\circ} \mathrm{C}$ & $\mathrm{RH}(\%)$ & $\mathrm{T}^{\circ} \mathrm{C}$ & $\mathrm{RH}(\%)$ \\
\hline 8-14 days & $32 \cdot 4 \pm 0 \cdot 39$ & $64 \pm 3 \cdot 7$ & $29 \cdot 2 \pm 0 \cdot 70$ & $73 \pm 4 \cdot 8$ \\
\hline 15-21 days & $32 \cdot 2 \pm 0 \cdot 77$ & $64 \pm 4 \cdot 7$ & $27 \cdot 1 \pm 0 \cdot 77$ & $73 \pm 4 \cdot 4$ \\
\hline 22-28 days & $32 \cdot 4 \pm 0 \cdot 16$ & $57 \pm 1 \cdot 9$ & $25 \cdot 0 \pm 0 \cdot 34$ & $65 \pm 1 \cdot 3$ \\
\hline 29-35 days & $32 \cdot 3 \pm 0 \cdot 31$ & $61 \pm 0 \cdot 9$ & $22 \cdot 9 \pm 0 \cdot 49$ & $70 \pm 1.9$ \\
\hline 36-42 days & $31 \cdot 9 \pm 0.57$ & $63 \pm 1 \cdot 6$ & $23 \cdot 9 \pm 0 \cdot 89$ & $72 \pm 2 \cdot 0$ \\
\hline
\end{tabular}

$\mathrm{HS} / \mathrm{AL}$, Ad libitum-fed heat-exposed; TN/PF, pair-feeding thermoneutral; $\mathrm{TN} / \mathrm{AL}$, thermoneutral ad libitum-fed; $\mathrm{T}^{\circ} \mathrm{C}$, environmental temperature; $\mathrm{RH}$, relative humidity.

Data are expressed as means \pm standard deviations.

mean intake of each broiler in each individual replicate (21 broilers by replicate). Then, the same amount of feed was provided to the corresponding TN/PF replicate. The temperature of the environments was measured every hour throughout the experiment and weekly averages of temperature are shown in Table 1. All broilers received the same starter (1-21 days) and grower diets (22-42 days) (Table A1 in the Appendix).

\section{Growth performance and body composition}

For performance analysis, broilers and feed were weighed at 21 and 42 days old. The following performance indicators were obtained for each experimental unit: $\mathrm{Fl}$, body weight gain (BWG) and feed conversion ratio $(\mathrm{FCR}=\mathrm{Fl} / \mathrm{BWG})$.

At 21 and 42 days of age, one broiler from each replicate was separated and fasted for $6 \mathrm{~h}$, then stunned by concussion and euthanized by bleeding. After slaughter, adipose tissue from the abdominal region surrounding the gizzard and between the intestines and abdominal wall was removed and weighed. The commercial cuts [breast, legs (thighs + drumsticks) and wings], with skin, were separated from the carcass and frozen at $-20{ }^{\circ} \mathrm{C}$ for composition analysis. The cuts were thawed in the laboratory, crushed in a commercial meat grinder, dried in a forced air oven $\left(55^{\circ} \mathrm{C}\right.$ for $72 \mathrm{~h}$ ) and ground using a grinder ball. The cuts were then analysed for dry matter (DM) content using a forced air oven for $12 \mathrm{~h}$ at $105^{\circ} \mathrm{C}$; thereafter complete combustion at $600{ }^{\circ} \mathrm{C}$ for $4 \mathrm{~h}$ was used to attain ash. The Soxhlet extraction method was performed to obtain ether extract (EE) and the microKjeldahl method was performed to obtain crude protein $(\mathrm{CP})$. All procedures were performed following the protocols of Silva \& Queiroz (2002).

Real-time quantitative polymerase chain reaction

Total RNA was extracted from the liver using a Ribopure Kit (Ambion ${ }^{\circledR}$ - Life Technologies, Waltham, MA, USA). The protocol for RNA extraction was modified by the addition of a DNase treatment between the two wash steps prior to the elution of RNA from the ceramic column. The first-strand cDNA synthesis was performed by reverse transcription (RT) from equal quantities $(5 \cdot 0 \mu \mathrm{g})$ of total RNA using the SuperScript III First-Strand Synthesis SuperMix (Invitrogen - Life Technologies, Carlsbad, USA). The protocol for firststrand cDNA synthesis was modified by the addition of a final step of digestion with RNase $\mathrm{H}(1 \mathrm{U})$ (Invitrogen) for $22 \mathrm{~min}$ at $37^{\circ} \mathrm{C}$. First-strand cDNAs were purified as described in Madsen et al. (2004) and was quantified in a NanoDrop spectrophotometer (ND-1000, Thermo Scientific, Waltham, USA). Working solutions were prepared and stored at $-20{ }^{\circ} \mathrm{C}$ until real-time quantitative polymerase chain reaction (RT-qPCR) was performed. The set of primers used to determine the expression of the target genes $(G H R$, IGF-I, IGF 1 receptor [IGF-IR], SREBP-1 and ChREBP) and reference genes (beta-actin $[A C T B]$, glyceraldehyde 3-phosphate dehydrogenase [GAPDH] and large ribosomal subunit [28S $r R N A]$ ) were designed using the Primer Express 3.0 software (Applied Biosystems - Life Technologies, Carlsbad, USA) (Table 2). To design the primers, previously described sequences of broiler genes from Genbank were used as reference. Furthermore, the primers were designed to amplify segments that contained at least one intron, which would eliminate the chance of amplifying residual genomic DNA.

Quantitative real-time PCR analysis was performed using the GeneAmp 7900 thermocycler (Applied Biosystems - Life Technologies, Carlsbad, USA) with the SYBR Green reagent (Invitrogen), following the protocol described by Coussens et al. (2003). The results of the RT-qPCR reactions were analysed with RQ Manager 1.2.1 (Applied Biosystems - Life Technologies, Carlsbad, USA) and the values of the quantification cycle (Cq) corrected for primer amplification efficiency and normalized using a control gene as described in Livak \& Schmittgen (2001). The amplification efficiency of the primers ranged from $90 \%$ to 
Table 2. Primers used for real-time $P C R^{a}$

\begin{tabular}{|c|c|c|c|c|}
\hline $\begin{array}{l}\text { Target } \\
\text { group }\end{array}$ & GenBank ID & Gene description & Sequence $\left(5^{\prime} 3^{\prime}\right)$, sense/antisense & $\begin{array}{l}\text { Amplicon size } \\
\text { (bp) }\end{array}$ \\
\hline$G H R$ & NM_001001293·1 & Growth hormone receptor & $\begin{array}{l}\text { GATGACTCCGATGAAAAGAACAGA } \\
\text { ATCCTTGGCTCCCAAGCAA }\end{array}$ & 93 \\
\hline $\mid G F-I$ & NM_001004384.2 & Insulin-like growth factor-1 & $\begin{array}{l}\text { TGGCCTGTGTTTGCTTACCTT/ } \\
\text { TACGAACTGAAGAGCATCAACCA }\end{array}$ & 91 \\
\hline$I G F-I R$ & NM_205032·1 & $\begin{array}{l}\text { Insulin-like growth factor-1 } \\
\text { receptor }\end{array}$ & $\begin{array}{l}\text { GGCCTGCCGCAATTACTACTA/ } \\
\text { CGCCAGCССТCAАACTTGT }\end{array}$ & 78 \\
\hline SREBP-1 & NM_204126·2 & $\begin{array}{l}\text { Sterol regulatory element- } \\
\text { binding protein }\end{array}$ & $\begin{array}{l}\text { CATCCATCAACGACAAGATCGT/ } \\
\text { CTCAGGATCGCCGACTTGTT }\end{array}$ & 82 \\
\hline ChREBP & NM_001110841·1 & $\begin{array}{l}\text { Carbohydrate response element } \\
\text { binding protein }\end{array}$ & $\begin{array}{l}\text { GAAGTTCTGGATCGTATCCTTTGG/ } \\
\text { TGGACCCAGTGTATGGTGGAA }\end{array}$ & 70 \\
\hline ACTB & NM_205518·1 & Cytoplasmic beta-actin & $\begin{array}{l}\text { TGGGTATGGAGTCCTGTGGT/ } \\
\text { AGGGCTGTGATCTCCTTCTG }\end{array}$ & 160 \\
\hline GAPDH & NM_204305·1 & $\begin{array}{l}\text { Glyceraldehyde-3-phosphate } \\
\text { dehydrogenase }\end{array}$ & $\begin{array}{l}\text { GGATACACAGAGGACCAGGTTGT/ } \\
\text { TTGCTGTATCCAAACTCATTGTCA }\end{array}$ & 143 \\
\hline $28 S$ rRNA & FM165415·2 & $28 \mathrm{~S}$ ribosomal RNA & $\begin{array}{l}\text { GGCGAAGCCAGAGGAAACT/ } \\
\text { GACGACCGATTTGCACGTC }\end{array}$ & 62 \\
\hline
\end{tabular}

a Primers designed by Primer Express software (Applied Biosystems - Life Technologies, Carlsbad, USA).

$110 \%$. The stability of expression was calculated using geNorm (https://genorm.cmgg.be/) and NormFinder (https://moma.dk/normfinder-software), considering $A C T B, G A P D H$ and $28 S$ rRNA as candidates, which revealed GAPDH to be the most accurate to normalize gene expression results in the present study.

\section{Statistical analysis}

Data from all variables were tested for the presence of outliers using residual analysis and for homoscedasticity and normality of studentized errors using Brown and Forsythe's and Cramer-von Mises tests, respectively. After the removal of outliers, all data presented agreement with the model assumptions. The General Linear Models procedure in SAS statistical software, version 9.3 (SAS Institute Inc 2011) was used to perform all the analysis. Analysis of variance with fixed effect of treatment and random effect of experimental unit was performed for each variable. The statistical model used for performance and gene expression was:

$$
Y_{i j}=\mu+T_{i}+\mathrm{EU}_{j}+e_{i j}
$$

where $Y_{i j}$ is the observation $i j ; \mu$ is the mean; $T_{i}$ is the fixed effect of treatment $i$; $\mathrm{EU}_{j}$ is the random effect of experimental unit; and $e_{i j}$ is the effect of error of replicate $i j$.
For body composition variables (DM, EE, CP and ash), body weight was included as a covariate, and the statistical model used was:

$$
Y_{i j k}=\mu+T_{i}+\mathrm{BW}_{j}+\mathrm{e}_{i j k}
$$

where $Y_{i j k}$ is the observation $i j k ; \mu$ is the mean; $T_{i}$ is the effect of treatment $i ; \mathrm{BW}_{j}$ is the effect of body weight; and $e_{i j}$ is the effect of error of replicate $i j$. When significant differences were found, the means were compared by Tukey's test at $P<0 \cdot 05$.

\section{RESULTS}

Growth performance and body composition

The broilers raised in the HS/AL treatment showed a lower FI and BWG $(P<0 \cdot 001)$ and a higher FCR $(P<0.001)$ throughout the experimental period as compared with the TN/AL (Table 3).

Abdominal fat values at $21(2,1$ and $2 \%$ for $\mathrm{HS} / \mathrm{AL}$, TN/PF and TN/AL, respectively) and 42 days of age did not vary among treatments.

Complete results of the chemical composition of commercial cuts (DM, CP, EE and ash) at 21 and 42 days are shown in Table A2. The amount of EE in commercial cuts was affected significantly by $\mathrm{HS}$, but not by feed consumption (Fig. 1). Thus, broilers from treatment $\mathrm{HS} / \mathrm{AL}$ had higher EE values $(P<0.05)$ in the breast and wings (only at 42 days) and lower EE $(P<$ 
Table 3. Growth performance of broilers for the 7-21 and 7-42 day periods

\begin{tabular}{|c|c|c|c|}
\hline Treatment & Feed intake (g) & Body weight gain (g) & Feed conversion rate $(\mathrm{g} / \mathrm{g})$ \\
\hline \multicolumn{4}{|l|}{ 7-21 days } \\
\hline $\mathrm{HS} / \mathrm{AL}$ & $946 \pm 20 \cdot 2$ & $690 \pm 14 \cdot 42$ & $1 \cdot 36 \pm 0 \cdot 01$ \\
\hline TN/PF & $887 \pm 18 \cdot 7$ & $613 \pm 12 \cdot 6$ & $1 \cdot 45 \pm 0 \cdot 01$ \\
\hline $\mathrm{TN} / A L$ & $1070 \pm 1 \cdot 3$ & $802 \pm 8 \cdot 9$ & $1 \cdot 33 \pm 0 \cdot 02$ \\
\hline CV $(\%)$ & $1 \cdot 82$ & $1 \cdot 80$ & $0 \cdot 97$ \\
\hline$P$-value ${ }^{\mathrm{a}}$ & $<0 \cdot 001$ & $<0 \cdot 001$ & $<0 \cdot 001$ \\
\hline \multicolumn{4}{|l|}{ 7-42 days } \\
\hline $\mathrm{HS} / \mathrm{AL}$ & $3420 \pm 157 \cdot 6$ & $1928 \pm 145 \cdot 3$ & $1 \cdot 78 \pm 0 \cdot 06$ \\
\hline TN/PF & $3356 \pm 137 \cdot 9$ & $1935 \pm 101 \cdot 6$ & $1 \cdot 74 \pm 0 \cdot 03$ \\
\hline $\mathrm{TN} / A L$ & $4639 \pm 59 \cdot 9$ & $2859 \pm 31 \cdot 9$ & $1 \cdot 62 \pm 0 \cdot 01$ \\
\hline CV (\%) & $3 \cdot 19$ & $4 \cdot 09$ & $1 \cdot 82$ \\
\hline$P$-value & $<0 \cdot 001$ & $<0 \cdot 001$ & $<0 \cdot 001$ \\
\hline
\end{tabular}

$\mathrm{HS} / \mathrm{AL}$, Ad libitum-fed heat-exposed; TN/PF, pair-feeding thermoneutral; TN/AL; thermoneutral ad libitum-fed, CV, coefficient of variation

a Tukey test.

Data are expressed as means \pm standard deviations.
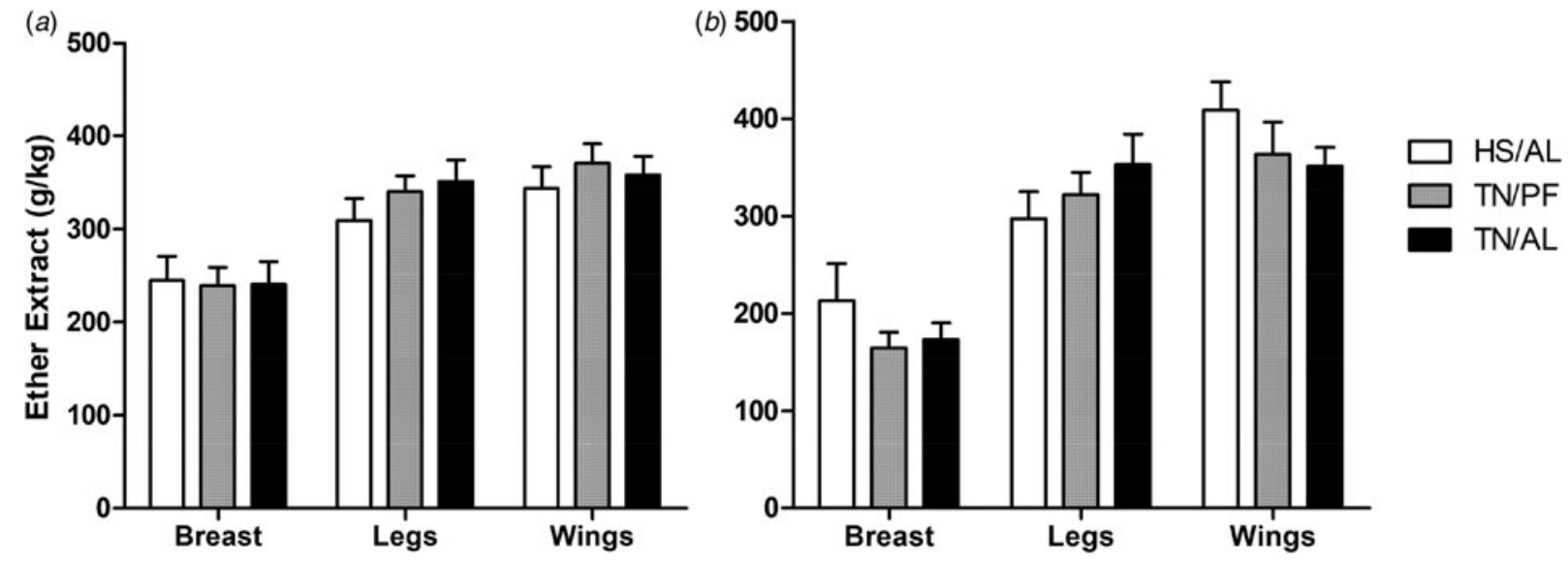

Fig. 1. Effect of heat stress and feed restriction on the ether extract content in retail cuts at 21 (a) and 42 days (b). Data are expressed as means. Vertical bars indicate the s.D. of mean. HS/AL, Ad libitum-fed heat-exposed; TN/PF, pair-feeding thermoneutral; TN/AL, thermoneutral ad libitum-fed.

0.05) in the legs (days 21 and 42) than those from the TN/AL group. Broilers from the HS/AL treatment had lower ash $(P<0.05)$ in the breast and higher DM $(P$ $<0.05)$ in the wings at 21 days, and lower DM $(P<$ $0 \cdot 05)$ in the legs at 42 days, when compared with broilers from the TN/AL treatment.

\section{Gene expression analysis}

Heat stress induced a more than three-fold increase of SREBP- 1 mRNA at 42 days $(P<0 \cdot 01)$ (Fig. 2). A similar difference was found at 21 days, though not statistically significant $(P=0 \cdot 079)$. Feed restriction was shown to induce a two-fold increase of SREBP-1
mRNA in both sampling ages, however, no statistical difference was detected. At 21 days, there was a decrease in GHR mRNA $(P<0 \cdot 05)$ in the TN/PF treatment, which was not detected at day 42 . Heat stress induced an increase in the expression of GHR $(P<$ $0 \cdot 05)$ at 42 days. The expression of other genes belonging to the somatotropic axis (IGF-I and IGF-IR) did not differ between treatments.

\section{DISCUSSION}

Heat stress is one of the major limiting factors for broiler growth, because the exposure of broilers to 

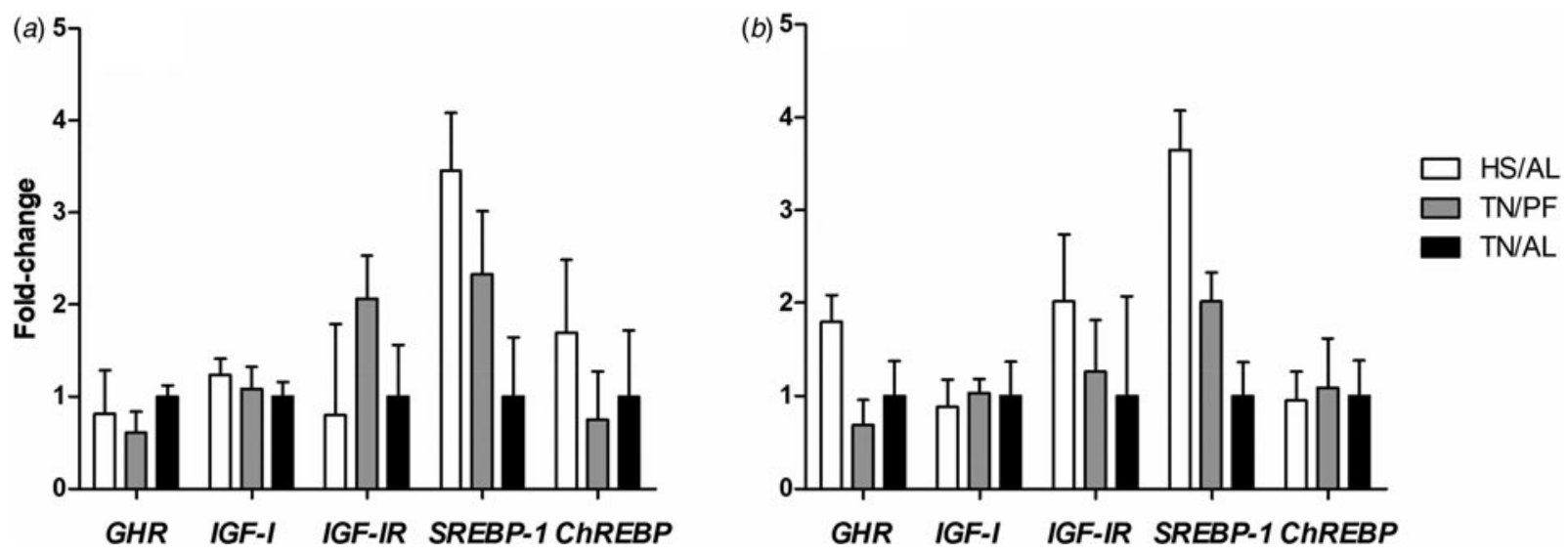

Fig. 2. Effect of heat stress and feed restriction on the expression of genes of the somatotropic axis and energetic metabolism at 21 (a) and 42 days (b). Data are expressed as fold-changes over TN/AL. Vertical bars indicate the s.D. of mean. HS/AL, Ad libitum-fed heat-exposed; TN/PF, pair-feeding thermoneutral; TN/AL, thermoneutral ad libitum-fed; GHR, growth hormone receptor; IGF-I, insulin-like growth factor-1; IGF-IR, insulin-like growth factor-1 receptor; SREBP-1, sterol regulatory element-binding protein 1; ChREBP, carbohydrate response element binding protein.

high environmental temperatures generates behavioural, physiological and immunological responses (Lara \& Rostagno 2013). The performance impairment causes great losses to the poultry industry: it is estimated that HS results in annual losses of US\$128165 million in the USA (St-Pierre et al. 2003). This is important both in tropical countries, where the temperature frequently exceeds $30^{\circ} \mathrm{C}$, and in temperate regions during the summer months. The findings of the current study confirm that broiler growth is reduced by HS, as reported previously (Campos et al. 2013; Zuo et al. 2015). These data confirm the hypothesis that reduction in $\mathrm{Fl}$ is the main cause of the effect on performance traits (Mignon-Grasteau et al. 2015).

In addition to concerns about performance impairment, previous studies have shown increased lipid deposition in the carcass of broilers reared with high temperatures (Baziz et al. 1996; Zhang et al. 2012). Similarly, in the current study, HS affected the concentration of EE in carcasses, but did not influence visceral fat deposition. In fact, the highest fat deposition in broilers reared under high temperature occurs in the subcutaneous and intermuscular tissues, with abdominal fat increasing only slightly (Baziz et al. 1996), or even being broken down (Toplu et al. 2014). The current data also showed increased lipid content in carcasses, in agreement with previous works (Baziz et al. 1996; Zhang et al. 2012), occurring specifically in the breast and wings, not proportionally throughout the whole carcass. Since these cuts accounted for $>40 \%$ of the carcass weight (data not shown), the increased lipid content in these areas are responsible for the increase in whole-carcass lipid content.

To analyse the mechanisms associated with changes in the composition of commercial cuts induced by HS and feed restriction, the expression of genes related to growth and energy metabolism was evaluated in the broilers' livers. The PF method allowed identification of a reduced concentration of GHR mRNA as a specific effect of feed restriction. Zhao et al. (2004) also observed a decrease in GHR mRNA as a result of feed restriction, but the experimental method used did not consider the effects of temperature. Because the circulating level of $\mathrm{GH}$ is higher in feed-restricted broilers (Gonzales et al. 1998), the decreased expression of GHR observed in the current work may reflect a downregulation of its receptors. Feed restriction was shown to induce a two-fold increase of SREBP-1 mRNA in broilers of 21 and 42 days of age, but no statistical significance was detected. The increase of SREBP-1 in the present study differs from previous studies, which found a lower expression of SREBP-1 in fasted broilers (Désert et al. 2008; Wang et al. 2009; Yang et al. 2010). The conflicting results may have occurred because the dietary restriction throughout the present study was approximately $30 \%$, whereas broilers in the other studies were fasted.

Heat stress did not affect the somatotropic axis genes evaluated at 21 days. At 42 days, however, the relative amount of $G H R$ mRNA was higher in the $\mathrm{HS} / \mathrm{AL}$ broilers. Expression of $\mathrm{GH}$ promotes metabolic responses to direct the energy for growth, suppressing 
lipogenesis and increasing hepatic gluconeogenesis (Schreibman 2012). On the other hand, broilers can increase hepatic lipogenesis by increasing GHR expression because this receptor reduces the lipolytic effect of GH via dimerization (Vasilatos-Younken 1995; Hausman et al. 2012). Thus, increased expression of GHR at 42 days may have increased lipogenesis, contributing to higher EE content in the breast and wings of the broilers exposed to HS.

The SREBP-1 results also indicate a lipogenic response in broilers subjected to HS. More specifically, the expression of SREBP-1 increased approximately 3.5 times at 42 days. Sterol-regulatory element-binding protein- 1 is a transcription factor that becomes stimulated with the presence of insulin and is responsible for regulating energy metabolism, leading to lipogenenesis (Desvergne et al. 2006). Previous studies have shown that broilers exposed to HS exhibit higher concentrations of plasma insulin (Sahin et al. 2002). In high temperatures, insulin regulates energy metabolism for higher use of carbohydrates and less oxidation of lipids (Rhoads et al. 2013). To the knowledge of the present authors, the present study is the first to show that $\mathrm{HS}$ increases $S R E B P-1$ gene expression in broilers. Assuming that insulin is the primary regulator of SREBP-1, the observed increase in SREBP-1 expression and associated fat deposition in broilers under HS may be regulated by increased levels of plasma insulin. Studies have not been performed to confirm the association of insulin, increases in fat deposition and SREBP-1 expression.

The evidence found relating to changes in the levels of SREBP-1 and GHR mRNA are indicative of these genes being involved in fat deposition in the carcass as a result of HS. To affirm the involvement of these genes in fat deposition, future studies should examine whether these observations are reflected at the protein level to fully and properly associate these mechanisms with the activity of these proteins.

The present study provides insights into the molecular mechanisms underlying fat deposition in broilers subjected to HS. The increased fat content in the carcass of broilers affected by HS appears to be regulated by distinct mechanisms, including reduced adipose tissue catabolism through higher GHR expression, as well as increased lipogenesis via SREBP-1 stimulation. The following two mechanisms could explain the difference in fat content between the commercial cuts in response to the specific effect of HS. The first is that increased hepatic lipogenesis and uniform triglyceride deposition in the carcass, with its higher utilization by the oxidative fibres of the legs (Baziz et al. 1996), leads to the reduction of fat reserves in the adipocytes of the legs. The second is that increased hepatic lipogenesis and heterogeneous triglyceride deposition in the carcass, with increased activation of adipocytes in the breast and wings to receive more triglycerides than those present in the legs. Further research must be performed to clarify the mechanisms responsible for the difference of the fat composition between the commercial cuts of broilers reared with high temperatures and to clarify how abdominal fat is not changed in such conditions.

In conclusion, regardless of the feed restriction imposed by chronic exposure to $32{ }^{\circ} \mathrm{C}$, HS increased fat content in the breast and wings and reduced the percentage of fat in the legs. The increased fat content in the breast and wings was accompanied by higher expression of $G H R$ and SREBP-1, suggesting the involvement of both genes in the control of fat deposition when exposed to high temperatures.

The authors would like to thank the São Paulo Research Foundation (FAPESP - Fundação de Amparo à Pesquisa do Estado de São Paulo - Process numbers 08/54579-1, 08/52533-4, and 12/03927-5) and the National Council for Scientific and Technological Development (CNPq Conselho Nacional de Desenvolvimento Científico e Tecnológico) for the financial support to conduct the research.

\section{REFERENCES}

Aвu-Dieyeh, Z. H. M. (2006). Effect of high temperature per se on growth performance of broilers. International Journal of Poultry Science 5, 19-21.

Anon (2003). Cobb 500 Broiler Management Guide. Siloam Springs, AR: Cobb-Vantress Inc.

ArNould, C. \& LeterRier, C (2007). Welfare of chickens reared for meat production. Production Animales 20, 41-45.

Baziz, H. A., Geraert, P. A., Padilha, J. C. F. \& Guillaumin, S. (1996). Chronic heat exposure enhances fat deposition and modifies muscle and fat partition in broiler carcasses. Poultry Science 75, 505-513.

Buyse, J. \& DeCuyPere, E. (1999). The role of the somatotropic axis in the metabolism of the chicken. Domestic Animal Endocrinology 17, 245-255.

Buyse, J., Decuypere, E., Darras, V.M., Vleurick, L.M. KuHN, E. R. \& Veldhuis, J. D. (2000). Food deprivation and feeding of broiler chickens is associated with rapid and interdependent changes in the somatotrophic and thyrotrophic axes. British Poultry Science 41, 107-116.

Campos, D. M. B., Fernandez-Alarcon, M. F., Souza, F. A., Nogueira, W. C. L., Hada, F. H., Carneiro, P.R. O. \& MACARI, M. (2013). Is high protein diet a good nutrition 
strategy for broiler chickens reared at heat stress condition? In Energy and Protein Metabolism and Nutrition in Sustainable Animal Production, Vol. 134. (Eds. J.W. Oltjen, E. Kebreab \& H. Lapierre), pp. 197-198. Energy and Protein Metabolism and Nutrition in Sustainable Animal Production series, EAAP. Wageningen, the Netherlands: Wageningen Academic Publishers.

Cheng, T. K., Hamre, M. L. \& CoOn, C. N. (1997). Responses of broilers to dietary protein levels and amino acid supplementation to low protein diets at various environmental temperatures. The Journal of Applied Poultry Research 6, 18-33.

Coussens, P. M., Colvin, C. J., Rosa, G. J. M., Laspiur, J. P. \& ElftMAn, M. D. (2003). Evidence for a novel gene blood expression program in peripheral mononuclear cells from Mycobacterium avium subsp. Paratuberculosisinfected cattle. Infection and Immunity 71, 6487-6498.

De Faria Filho, D. E., Campos, D. M. B., Alfonso-Torres, K. A., Vieira, B.S., Rosa, P.S., Vaz, A.M., Macarl, M. \& FurLAN, R. L. (2007). Protein levels for heat-exposed broilers: performance, nutrients digestibility, and energy and protein metabolism. International Journal of Poultry Science 6, 187-194.

Désert, C., Duclos, M. J., Blavy, P., Lecerf, F., Moreews, F., Klopp, C., Aubry, M., Herault, F., Le Roy, P., Berri, C., Douaire, M., Diot, C. \& Lagarrigue, S. (2008). Transcriptome profiling of the feeding-to-fasting transition in chicken liver. BMC Genomics 9, 611. Available from: https://doi.org/10.1186/1471-2164-9-611

Desvergne, B., Michalik, L. \& Wahli, W. (2006). Transcriptional regulation of metabolism. Physiological Reviews 86, 465-514.

Estevez, I. (2007). Density allowances for broilers: where to set the limits? Poultry Science 86, 1265-1272.

Food and Agriculture Organization of United Nations - FAO (2012). FAOSTAT Database. Rome, Italy: FAO. Available from: http://faostat3.fao.org/home/E (verified 18 August 2017).

Geraert, P.A., Padilha, J. C. F. \& Guillaumin, S. (1996). Metabolic and endocrine changes induced by chronic heat exposure in broiler chickens: growth performance, body composition and energy retention. British Journal of Nutrition 75, 195-204.

Gonzales, E., Buyse, J., Loddi, M. M., Takita, T. S., Buys, N. \& DeCuypere, E. (1998). Performance, incidence of metabolic disturbances and endocrine variables of food-restricted male broiler chickens. British Poultry Science 39, 671-678.

Hausman, G. J., Barb, C. R., Fairchild, B. D., Gamble, J. \& LeeRUTHERFORD, L. (2012). Expression of genes for interleukins, neuropeptides, growth hormone receptor, and leptin receptor in adipose tissue from growing broiler chickens. Domestic Animal Endocrinology 43, 260-263.

Hillgartner, F. B., Salati, L. M. \& Goodridge, A. G. (1995). Physiological and molecular mechanisms involved in nutritional regulation of fatty acid synthesis. Physiological Reviews 75, 47-76.

KITA, K. (1998). Refeeding increases hepatic insulin-like growth factor-I (IGF-I) gene expression and plasma IGF-I concentration in fasted chicks. British Poultry Science 39, 679-682.
LaRa, L. J. \& Rostagno, M. H. (2013). Impact of heat stress on poultry production. Animals 3, 356-369.

LivaK, K. J. \& SChmitTGen, T. D. (2001). Analysis of relative gene expression data using real-time quantitative PCR and the 2 (-Delta Delta C (T)) method. Methods 25, 402-408.

Madsen, S. A., Chang, L.-C., Hickey, M.-C., Rosa, G. J. M., Coussens, P. M. \& BuRTON, J. L. (2004). Microarray analysis of gene expression in blood neutrophils of parturient cows. Physiological Genomics 16, 212-221.

Mignon-Grasteau, S., Moreri, U., Narcy, A., Rousseau, X., Rodenburg, T. B., Tixier-Boichard, M. \& Zerjal, T (2015). Robustness to chronic heat stress in laying hens: a metaanalysis. Poultry Science 94, 586-600.

Oliveira Neto, A. R. D., Oliveira, R. F. M. D., Donzele, J. L., Rostagno, H.S., Ferreira, R. A., Maximiano, H. D.C. \& GASPARINO, E. (2000). Effect of environment temperature on performance and carcass characteristics in broilers pair-fed and two levels of metabolizable energy. Revista Brasileira de Zootecnia 29, 183-190.

Proszkowiec-Weglarz, M., Richards, M. P., Humphrey, B. D., Rosebrough, R. W. \& McMurtry, J.P. (2009). AMP-activated protein kinase and carbohydrate response element binding protein: a study of two potential regulatory factors in the hepatic lipogenic program of broiler chickens. Comparative Biochemistry and Physiology Part B: Biochemistry and Molecular Biology 154, 68-79.

Rhoads, R. P., Baumgard, L. H., Suagee, J. K. \& Sanders, S. R. (2013). Nutritional interventions to alleviate the negative consequences of heat stress. Advances in Nutrition: An International Review Journal 4, 267-276.

Richards, M. P., Poch, S. M., Coon, C. N., Rosebrough, R. W., AshWELL, C. M. \& MCMurtRY, J.P. (2003). Feed restriction significantly alters lipogenic gene expression in broiler breeder chickens. The Journal of Nutrition 133, 707-715.

Sahin, K., Sahin, N., Onderci, M., Gursu, F. \& Cikim, G. (2002). Optimal dietary concentration of chromium for alleviating the effect of heat stress on growth, carcass qualities, and some serum metabolites of broiler chickens. Biological Trace Element Research 89, 53-64.

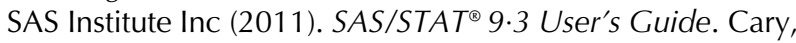
NC: SAS Inst. Inc.

SChreibMAN, M. (2012). The Endocrinology of Growth, Development, and Metabolism in Vertebrates. New York, USA: Academic Press.

Shimano, H., Yahagl, N., AmemiYa-Kudo, M., Hasty, A. H., Osuga, J.-I., TAMURA, Y., SHIONOIRI, F., IIZUKA, Y., OhashI, K., HaRAda, K., GOtOda, T., Ishibashi, S. \& YAMADA, N. (1999). Sterol regulatory element-binding protein-1 as a key transcription factor for nutritional induction of lipogenic enzyme genes. Journal of Biological Chemistry 274, 35832-35839.

Silva, D. \& Queiroz, A. D. (2002). Análise de Alimentos: Métodos Químicos e Biológicos, 3rd edn, Viçosa, MG, Brazil: Universidade Federal de Viçosa.

St-Pierre, N.R., Cobanov, B. \& Schnitkey, G. (2003). Economic losses from heat stress by US livestock industries. Journal of Dairy Science $\mathbf{8 6}$ (Suppl), E52-E77.

Toplu, H. D. O., Oral, D., Nazligul, A., Karaarslan, S., KAYA, M. \& YAGIN, O. (2014). Effects of heat conditioning 
and dietary ascorbic acid supplementation on growth performance, carcass and meat quality characteristics in heat-stressed broilers. Ankara Üniversitesi Veteriner Fakültesi Dergisi 61, 295-302.

Vasilatos-Younken, R. (1995). Proposed mechanisms for the regulation of growth hormone action in poultry: metabolic effects. The Journal of Nutrition 125 (Suppl), 1783S-1789S.

Wang, P. H., Ko, Y.H., Chin, H.J., Hsu, C., Ding, S.T. \& CHEN, C. Y. (2009). The effect of feed restriction on expression of hepatic lipogenic genes in broiler chickens and the function of SREBP1. Comparative Biochemistry and Physiology Part B: Biochemistry and Molecular Biology 153, 327-331.

YANG, X., ZhuanG, J., RaO, K., LI, X. \& ZHAO, R. (2010). Effect of early feed restriction on hepatic lipid metabolism and expression of lipogenic genes in broiler chickens. Research in Veterinary Science 89, 438-444.

ZhanG, Z. Y., JIA, G. Q., ZuO, J. J., ZhanG, Y., Lel, J., Ren, L. \& FENG, D. Y. (2012). Effects of constant and cyclic heat stress on muscle metabolism and meat quality of broiler breast fillet and thigh meat. Poultry Science 91, 2931-2937.

Zhao, R., Muehlbauer, E., Decuypere, E. \& Grossmann, R. (2004). Effect of genotype-nutrition on growth and somatotropic gene expression in the chicken. General and Comparative Endocrinology 136, 2-11.

Zuo, J., Xu, M., Abdullahi, Y. A., Ma, L., Zhang, Z. \& Feng, D. (2015). Constant heat stress reduces skeletal muscle protein deposition in broilers. Journal of the Science of Food and Agriculture 95, 429-436.

\section{APPENDIX}

Table A1. Composition of starter (1-21 days) and grower (22-42 days) diets for broilers

\begin{tabular}{|c|c|c|}
\hline Parameters & Starter & Grower \\
\hline \multicolumn{3}{|l|}{ Components (g/100 g mixture) } \\
\hline Maize & $57 \cdot 96$ & $58 \cdot 47$ \\
\hline Soybean meal (45\%) & $35 \cdot 62$ & $32 \cdot 42$ \\
\hline Soybean oil & $2 \cdot 57$ & $5 \cdot 47$ \\
\hline Dicalcium phosphate & $1 \cdot 82$ & $1 \cdot 68$ \\
\hline Limestone & 0.99 & 0.95 \\
\hline Salt & $0 \cdot 44$ & $0 \cdot 40$ \\
\hline DL-methionine & $0 \cdot 15$ & $0 \cdot 14$ \\
\hline L-lysine & $0 \cdot 16$ & $0 \cdot 18$ \\
\hline Mineral-vitamin premix ${ }^{a}$ & $0 \cdot 10$ & $0 \cdot 10$ \\
\hline Choline chloride & $0 \cdot 10$ & $0 \cdot 10$ \\
\hline Antibiotic $^{\mathrm{b}}$ & $0 \cdot 04$ & $0 \cdot 04$ \\
\hline Coccidiostat $^{\mathrm{c}}$ & $0 \cdot 05$ & $0 \cdot 05$ \\
\hline $\mathrm{ME}(\mathrm{MJ} / \mathrm{kg})$ & $12 \cdot 56$ & $13 \cdot 40$ \\
\hline Crude protein & $21 \cdot 4$ & $20 \cdot 0$ \\
\hline Calcium & 0.96 & 0.90 \\
\hline Available phosphorus & $0 \cdot 45$ & $0 \cdot 42$ \\
\hline Sodium & $0 \cdot 22$ & $0 \cdot 20$ \\
\hline Potassium & $0 \cdot 84$ & $0 \cdot 77$ \\
\hline Chloride & $0 \cdot 37$ & $0 \cdot 35$ \\
\hline Choline (ppm) & 1950 & 1868 \\
\hline Digestible lysine & $1 \cdot 14$ & $1 \cdot 08$ \\
\hline Digestible methionine & $0 \cdot 45$ & $0 \cdot 42$ \\
\hline
\end{tabular}

${ }^{a}$ Mineral-vitamin premix supplied (kg of product): Zn - 91250 mg, Cu - 10000 mg, Mn - 76260 mg, I-13000 mg, Se -273.6 mg, niacin - $34650 \mathrm{mg}$, biotin $-1600 \mathrm{mg}$, pantothenate $-9500 \mathrm{mg}$, retinol $-7000000 \mathrm{UI}$, thiamine $-1780 \mathrm{mg}$, cyanacobalamin $10000 \mathrm{mcg}$, riboflavin - $9600 \mathrm{mg}$, pyridoxine - $3465 \mathrm{mg}$, cholecalciferol -3000000 UI, DL- $\alpha$-tocopherol - $25000 \mathrm{mg}$, menadione $980 \mathrm{mg}$, antioxidant $-100 \mathrm{mg}$.

b Zinc bacitracin $15 \%$.

${ }^{\mathrm{c}}$ Coxistac $^{\circledR} 12 \%$. 
Table A2. Carcass parts composition of broilers at 21 and 42 days

\begin{tabular}{|c|c|c|c|c|c|c|}
\hline \multirow[b]{2}{*}{ Parts } & & \multicolumn{3}{|l|}{ Treatment } & \multirow[b]{2}{*}{ CV (\%) } & \multirow[b]{2}{*}{$P$-value ${ }^{a}$} \\
\hline & & $\mathrm{HS} / \mathrm{AL}$ & $\mathrm{TN} / \mathrm{PF}$ & $\mathrm{TN} / A L$ & & \\
\hline \multirow{7}{*}{ Breast } & & & 21 days & & & \\
\hline & BW & $816 \pm 21$ & $746 \pm 17$ & $924 \pm 7$ & $2 \cdot 25$ & $<0 \cdot 05$ \\
\hline & $\mathrm{DM}^{+}$ & $303 \pm 10$ & $306 \pm 12$ & $301 \pm 11$ & $3 \cdot 41$ & NS \\
\hline & $\mathrm{CP}$ & $727 \pm 31$ & $736 \pm 27$ & $721 \pm 34$ & $4 \cdot 17$ & NS \\
\hline & $\mathrm{EE}$ & $245 \pm 27$ & $239 \pm 20$ & $241 \pm 25$ & $10 \cdot 18$ & NS \\
\hline & Ash & $47 \pm 10$ & $61 \pm 6$ & $59 \pm 8$ & $15 \cdot 13$ & $<0.05$ \\
\hline & DM & $315 \pm 11$ & $325 \pm 11$ & $324 \pm 11$ & $3 \cdot 33$ & NS \\
\hline \multirow[t]{4}{*}{ Legs } & $\mathrm{CP}$ & $583 \pm 50$ & $565 \pm 34$ & $544 \pm 37$ & $6 \cdot 95$ & NS \\
\hline & $\mathrm{EE}$ & $310 \pm 23$ & $340 \pm 17$ & $351 \pm 23$ & $6 \cdot 47$ & $<0.05$ \\
\hline & Ash & $65 \pm 15$ & $65 \pm 12$ & $56 \pm 8$ & $20 \cdot 12$ & NS \\
\hline & DM & $349 \pm 9$ & $346 \pm 8$ & $334 \pm 9$ & $2 \cdot 63$ & $<0.05$ \\
\hline \multirow[t]{5}{*}{ Wing } & $\mathrm{CP}$ & $536 \pm 12$ & $526 \pm 25$ & $530 \pm 20$ & $2 \cdot 31$ & NS \\
\hline & $\mathrm{EE}$ & $343 \pm 23$ & $371 \pm 21$ & $359 \pm 20$ & $5 \cdot 95$ & NS \\
\hline & Ash & $124 \pm 17$ & $\begin{array}{l}120 \pm 19 \\
42 \text { days }\end{array}$ & $113 \pm 13$ & $5 \cdot 75$ & NS \\
\hline & BW & $2046 \pm 94 \cdot 4$ & $2071 \pm 101 \cdot 0$ & $2904 \pm 55 \cdot 1$ & $3 \cdot 67$ & $<0 \cdot 05$ \\
\hline & DM & $285 \pm 14$ & $290 \pm 12$ & $281 \pm 13$ & $4 \cdot 78$ & NS \\
\hline \multirow[t]{4}{*}{ Breast } & $\mathrm{CP}$ & $677 \pm 56$ & $685 \pm 56$ & $694 \pm 32$ & $7 \cdot 36$ & NS \\
\hline & $\mathrm{EE}$ & $227 \pm 51$ & $164 \pm 16$ & $173 \pm 17$ & $14 \cdot 16$ & $<0.05$ \\
\hline & Ash & $41 \pm 13$ & $36 \pm 6$ & $33 \pm 11$ & $29 \cdot 23$ & NS \\
\hline & DM & $295 \pm 13$ & $312 \pm 19$ & $325 \pm 18$ & $5 \cdot 47$ & $<0 \cdot 05$ \\
\hline \multirow[t]{4}{*}{ Legs } & $\mathrm{CP}$ & $489 \pm 74$ & $481 \pm 43$ & $464 \pm 29$ & $7 \cdot 01$ & $<0.05$ \\
\hline & $\mathrm{EE}$ & $318 \pm 61$ & $322 \pm 23$ & $353 \pm 31$ & $7 \cdot 76$ & $<0.05$ \\
\hline & Ash & $37 \pm 9$ & $52 \pm 7$ & $45 \pm 6$ & $17 \cdot 01$ & $<0 \cdot 05$ \\
\hline & DM & $352 \pm 21$ & $349 \pm 9$ & $356 \pm 9$ & $2 \cdot 91$ & NS \\
\hline \multirow[t]{3}{*}{ Wing } & $\mathrm{CP}$ & $487 \pm 26$ & $468 \pm 22$ & $476 \pm 36$ & $5 \cdot 07$ & NS \\
\hline & $\mathrm{EE}$ & $408 \pm 30$ & $363 \pm 33$ & $351 \pm 19$ & $7 \cdot 63$ & $<0.05$ \\
\hline & Ash & $61 \pm 17$ & $64 \pm 4$ & $51 \pm 15$ & $19 \cdot 16$ & NS \\
\hline
\end{tabular}

$\mathrm{HS} / \mathrm{AL}$, Ad libitum-fed heat-exposed; TN/PF, pair-feeding thermoneutral; TN/AL, thermoneutral Ad libitum-fed; DM, dry matter $(\mathrm{g} / \mathrm{kg})$; $\mathrm{CP}$, crude protein; $\mathrm{EE}$, ether extract and ash are presented as $\mathrm{g} / \mathrm{kg}$ efficient of variation.

a Tukey test for fixed effect (treatment).

Data are expressed as means \pm standard deviations. 